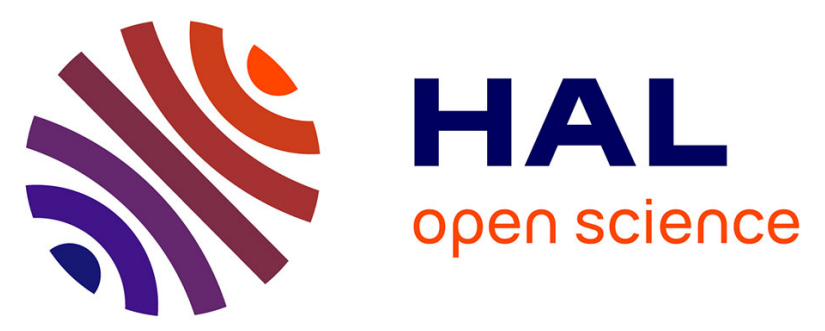

\title{
Antioxidant and enzymatic responses to oxidative stress induced by pre-harvest water supply reduction and ripening on mango (Mangifera indica L. cv. 'Cogshall') in relation to carotenoid content
}

Rémy Rosalie, Jacques Joas, Christelle Deytieux-Belleau, Emmanuelle

Vulcain, Bertrand Payet, Laurent Dufossé, Mathieu Léchaudel

\section{To cite this version:}

Rémy Rosalie, Jacques Joas, Christelle Deytieux-Belleau, Emmanuelle Vulcain, Bertrand Payet, et al.. Antioxidant and enzymatic responses to oxidative stress induced by pre-harvest water supply reduction and ripening on mango (Mangifera indica L. cv. 'Cogshall') in relation to carotenoid content. Journal of Plant Physiology, 2015, 184, pp.68 - 78. 10.1016/j.jplph.2015.05.019 . hal-01397519

\section{HAL Id: hal-01397519 \\ https://hal.univ-reunion.fr/hal-01397519}

Submitted on 16 Nov 2016

HAL is a multi-disciplinary open access archive for the deposit and dissemination of scientific research documents, whether they are published or not. The documents may come from teaching and research institutions in France or abroad, or from public or private research centers.
L'archive ouverte pluridisciplinaire HAL, est destinée au dépôt et à la diffusion de documents scientifiques de niveau recherche, publiés ou non, émanant des établissements d'enseignement et de recherche français ou étrangers, des laboratoires publics ou privés. 


\title{
Antioxidant and enzymatic responses to oxidative stress induced by pre-harvest water supply reduction and ripening on mango (Mangifera indica L. cv. 'Cogshall') in relation to carotenoid content
}

\author{
Rémy Rosalie a,b, ${ }^{*}$, Jacques Joas ${ }^{c}$, Christelle Deytieux-Belleau ${ }^{\mathrm{a}}$, Emmanuelle Vulcain ${ }^{\mathrm{a}}$, \\ Bertrand Payet $^{\mathrm{b}}$, Laurent Dufosséd ${ }^{\text {, Mathieu Léchaudel }}{ }^{\mathrm{e}}$ \\ a Centre de Coopération Internationale de Recherche Agronomique pour le Développement (CIRAD), UMR Qualisud, 7 Rue de l'Irat, 97410 Saint-Pierre, Ile de La Réunion, France \\ ${ }^{\mathrm{b}}$ Laboratoire de Chimie des Substances Naturelles et des Sciences des Aliments, Faculté des Sciences et Technologies, Université de La Réunion, \\ Sainte-Clotilde, Ile de la Réunion, France \\ ' CIRAD, UMR Qualisud, TA B95/16, 73 rue Jean-François Breton, 34398, Montpellier Cedex 5, France \\ d Laboratoire de Chimie des Substances Naturelles et des Sciences des Aliments, Université de La Réunion, ESIROI Agroalimentaire, Parc Technologique, 2 rue Joseph Wetzell, 97490, \\ Sainte-Clotilde, Ile de la Réunion, France \\ e CIRAD, UR Fonctionnement Agroécologique et Performances des Systèmes de Culture Horticoles, Station Bassin Plat, BP 180, 97455, Saint Pierre Cedex, Ile de la Réunion, France
}

The effects of a reduction in water supply during fruit development and postharvest fruit ripening on the oxidative status and the antioxidant defense system were studied in the mango fruit (Mangifera indica L.) cv. Cogshall. Changes in non-enzymatic (ascorbate) and enzymatic (SOD, CAT, APX, MDHAR, DHAR and GR) antioxidants, as well as oxidative parameters ( $\mathrm{H}_{2} \mathrm{O}_{2}$ and MDA) and major carotenoids, were measured in unripe and ripe fruits from well-irrigated and non-irrigated trees. Under non-limiting water supply conditions, ripening induced oxidation as a result of the production of ROS and decreased ascor-bate content. Antioxidant enzymatic systems were activated to protect fruit tissues and to regenerate the ascorbate pool. The carotenoid pool, mainly represented by $\beta$-carotene and esterified violaxanthine iso-mers, accumulated naturally during mango ripening. The suppression of irrigation decreased fruit size and induced accumulation of ABA and of its storage form, ABA-GE, in fruit pulp from the earliest harvest. It also increased oxidation, which was observable by the high levels of ascorbate measured at the early stages at harvest, and by the delay in the time it took to reach the pseudo constant carotene-to-xanthophyll ratio in ripe fruits. Nevertheless, differences between the irrigation treatments on the antioxidant system in ripe fruits were not significant, mainly because of the drastic changes in this system during ripening.

\section{Introduction}

Plants submitted to biotic and abiotic stressful conditions such as high light exposure, drought, salt stress, ripening or pathogen attack (Dat et al., 2000) are characterized by the transient increase in the production of reactive oxygen species (ROS). ROS are low molecular weight compounds produced naturally by organelles as by-products of electron transfer chains and highly oxidizing enzy-

* Corresponding author at: Centre de Coopération Internationale de Recherche Agronomique pour le Développement (CIRAD), UMR Qualisud, 7 Rue de l'Irat, 97410 Saint-Pierre, Ile de La Réunion, France.

E-mail address: rosalie.remy@gmail.com (R. Rosalie). matic reactions. They play two very specific roles: (1) signaling the activation of defense responses at low concentrations; and (2) exacerbating damage at higher contents, leading to oxidative damage to amino acids, lipids and nucleic acid (Mittler and Vanderauwera, 2004). It is therefore a primary challenge for plants to maintain their ROS content at a balanced level to avoid unwanted damage. In order to limit ROS accumulation in tissues, plants maintain both molecular and enzymatic antioxidant activities. Carotenoids and ascorbate (AsA) play important roles as molecular antioxidants by providing reducing power to overcome the oxidation source. Ascorbate can directly scavenge some species of reactive oxygen $\left(\mathrm{O}_{2}{ }^{\bullet}, \mathrm{H}_{2} \mathrm{O}_{2}\right)$ and reduce $\mathrm{H}_{2} \mathrm{O}_{2}$ via ascorbate peroxidase (APX) (Blokhina, 2003). APX takes part in the ascorbate-glutathione cycle in which $\mathrm{H}_{2} \mathrm{O}_{2}$ molecules are reduced to water by oxidizing ascorbate to monode- 
hydroascorbate (MDHA) and dehydroascorbate (DHA) molecules. In this cycle, monodehydroascorbate reductase (MDHAR), dehydroascorbate reductase (DHAR) and glutathione reductase (GR) are responsible for successively reducing MDHA, DHA and glutathione using NADH, GSH and NADPH as redox cofactors, in order to regenerate the active form of ascorbate.

Fruit ripening involves major changes in cellular metabolism: color, sugar content, aroma and taste. Most of these changes are balanced by hormonal signals such as ethylene and abscisic acid (ABA) (Zhang et al., 2009), according to the climacteric or nonclimacteric status of the fruit. Fruit ripening has been described as an oxidative phenomenon and in the case of climacteric fruits, the increase in respiration rate during the climacteric crisis leads to an overproduction of ROS. Moreover, ROS accumulation results in lipid peroxidation in cellular membranes, leading to an end product of these radical reactions, malondialdehyde (MDA), generally considered an indicator of membrane destruction (Gill and Tuteja, 2010). There must therefore be a balance between the production of ROS and their regulation by antioxidant systems to limit oxidative alterations linked in part to fruit senescence. Responses in the enzymatic and non-enzymatic antioxidant systems have been observed during the ripening of climacteric fruit such as tomato and plum (Singh et al., 2012). Limitation in water availability is the major environmental factor limiting fruit production, resulting in lower yields and smaller fruits. Fruit quality is also affected because water deprivation unbalances fruit metabolism (Spreer et al., 2009). This limitation as occurring during the cell expansion phase and that of $\mathrm{CO}_{2}$ availability for photosynthesis are two parameters that play a role in the growth limitation that occurs during water stress. In fruits, few studies have been carried out to determine how ABA and ROS are influenced by the limitation of irrigation. Studies on the role of the antioxidant defense systems in response to low or non-irrigated cultures are scarce, with the exception of tomato fruit. In studies on tomato fruit, drought stress consistently increased lycopene and total carotenoids, whereas ascorbate contents increased or decreased according to the cultivars studied and the drought intensity (Stefanelli et al., 2010). The aim of this study was therefore to evaluate the incidence of the suppression of irrigation during fruit development and the postharvest fruit ripening on the oxidative stress and the antioxidant defense system in relation to carotenoid content.

The case of mango was taken as a reference because it is a tropical fruit of major economic importance and water deprivation is frequently encountered in orchards. Moreover, one of the interests of this climacteric fruit is its excellent nutritional properties, due in particular to its carotenoid and ascorbic acid contents (Taylor and Masibo, 2012). It is therefore necessary to investigate its response under such conditions. The effect of the suppression of irrigation during fruit growth on the balance between the oxidative stress and the antioxidant system was evaluated by comparing two contrasted irrigation conditions, i.e., control trees that were fully irrigated to fulfill their daily evapotranspiration and non-irrigated trees. Mango ripening was then analyzed at various maturity stages at harvest on the basis of changes in the oxidative parameters, the molecular and enzymatic antioxidant systems, and the main forms of carotenoids in the pulp.

\section{Material and methods}

\subsection{Plant and fruit material}

This study was conducted on mango trees of cv. Cogshall, grafted on Maison Rouge, in Reunion Island $\left(20^{\circ} 52^{\prime} 48^{\prime \prime} \mathrm{S}, 55^{\circ} 31^{\prime} 48^{\prime \prime} \mathrm{E}\right)$ at the CIRAD experimental station, at an elevation of $95 \mathrm{~m}$, during the 2010-2011 growing season. Trees were grown in two orchards distant by a few meters. One orchard, which is referred to as the 'control,' was well irrigated and a second orchard, located closed to the control, was deprived of water after full bloom.

The amount of water used for irrigation of the control orchard was calculated from an average reference evapotranspiration $\left(\mathrm{ET}_{0}\right)$, based on the FAO Penman-Monteith method (Allen et al., 1998), recorded during the period of mango production in the area of the orchard, which was equal to $4 \mathrm{~mm}$. Thus, water irrigation supplied daily to mango trees (in $\mathrm{m}^{3}$ ) corresponded to the half of this average multiplied by the irrigated surface (in $\mathrm{m}^{2}$ ). Every ten days, water requirement for trees was controlled by using a user-friendly computer program, called PROBE (Chopart and Vauclin, 1990; Chopart et al., 2009), which models crop-specific water requirement based on a water balance. Changes in soil water storage were calculated daily from the maximal available water storage, derived from soil characteristics (Raunet and Langellier, 2011), water excess, climatic and cultural data (for $\mathrm{ET}_{\mathrm{C}}$ calculation, since tree irrigation was considered to be optimal Allen et al., 1998), rainwater and irrigation input. The crop evapotranspiration, $\mathrm{ET}_{\mathrm{c}}$, was derived from $\mathrm{ET}_{0}$ and the crop coefficient $\left(K_{\mathrm{c}}\right)$ for mango, equal to 0.5 and 0.8 during the flowering and fruit growth periods, respectively (Azevedo de et al., 2003).

If the climatic condition involved a strong increase in $\mathrm{ET}_{0}$, exceeding the average value used for the irrigation calculation, then the soil water storage decreased. If the soil water storage decreased to below $60 \%$ of the maximal available water storage, the daily amount of water supplied by irrigation was multiplied by two over 5 days. Trees from the non-irrigated orchard received only rainwater.

Chlorophyll fluorescence parameters, i.e., minimal and maximal chlorophyll fluorescence ( $F_{\mathrm{o}}$ and $F_{\mathrm{m}}$, respectively), and the variable chlorophyll fluorescence $\left(F_{\mathrm{v}}=F_{\mathrm{m}}-F_{\mathrm{o}}\right)$, were measured on the fruit surface near the apex zone where the first changes in peel color appear in order to assess the degree of mango maturity, regardless of fruit growing conditions (Lechaudel et al., 2010). Three maturity stages corresponding to three different values of the variable chlorophyll fluorescence $\left(F_{\mathrm{v}}\right)$ parameter were chosen: approximately 1400,1250 , and 950 for $\mathrm{H} 1, \mathrm{H} 2$, and $\mathrm{H} 3$, respectively. $\mathrm{H} 1$ and $\mathrm{H} 2$ corresponded to two green mature and commercial maturity stages that allow a cold storage of two to three weeks in order to supply local markets and some export markets. The third harvest stage, $\mathrm{H} 3$, corresponded to a maturity stage when the fruit's apex has started to lose its green color and became yellow, referred to as the yellow point stage (YPS), a typical stage for this variety, indicating the onset of the climacteric process. It was assumed that fruits harvested at the YPS presented the best quality potential (Joas et al., 2004). For each treatment and each maturity stage, eight fruits were harvested. Four fruits were sampled for analysis at harvest, corresponding to these $\mathrm{H} 1, \mathrm{H} 2$ and $\mathrm{H} 3$ stages. The remaining four fruits were stored for ripening in controlled conditions $\left(20^{\circ} \mathrm{C}\right.$ and $90 \%$ relative humidity $(\mathrm{RH})$ ).

\subsection{Postharvest and quality measurements}

To ensure that ripe fruits had the same physiological age when analyzed, respiratory metabolism and climacteric rise were used as indicators (Joas et al., 2009). Each of the fruits was monitored daily to follow the changes in respiration rate (RR). Respiration rate was expressed in terms of $\mathrm{CO}_{2}$ production at $20^{\circ} \mathrm{C}\left(\mathrm{mmol} \mathrm{kg}^{-1} \mathrm{~h}^{-1}\right)$ using a closed system method. Fruits from each treatment were placed in individual 3-L airtight jars at $20^{\circ} \mathrm{C}$, and $\mathrm{CO}_{2}$ concentration was measured every $20 \mathrm{~min}$ for $1 \mathrm{~h}$ by gas chromatography (GC) using an Agilent M200 apparatus (SRA, Marcy l'Etoile, France), equipped with two manifolds and two columns: Porapak Q $(8 \mathrm{~m})$, thermostated at $55^{\circ} \mathrm{C}$, and MS-5A $(4 \mathrm{~m})$, thermostated at $60^{\circ} \mathrm{C}$, with helium and argon as carrier gases, respectively. 
Fruit sampling was done at the ripe stage (corresponding to $\mathrm{R} 1-\mathrm{R} 3$, according to the three harvest stages). Four ripe fruits were analyzed 3 days after they had reached the highest value of their respiration rate, corresponding to the "ready-to-eat" stage.

Sampling conditions were established to limit matrix degradation linked to light, temperature and enzymatic activity. Fruits were peeled, cut and part of the pulp was ground in a Grindomix blender (Retsch, Haan, Germany) to obtain a juice for the measurement of total soluble solids (TSS) content and titratable acidity (TA), and the other part was immediately wrapped in an alumina sheet and dipped in liquid nitrogen. These frozen pulps were ground in a Grindomix blender and the powders obtained were stored in opaque plastic pots at $-80^{\circ} \mathrm{C}$ for future analysis.

A sample of each frozen powder was used for dry matter content assessment, done by comparing its fresh mass and its dry mass recorded after lyophilization, performed over $48 \mathrm{~h}$ at $-52^{\circ} \mathrm{C}$. Lyophilization was used to dry a part of each sample for carotenoid analysis. Lyophilization was performed over $48 \mathrm{~h}$ at $-52^{\circ} \mathrm{C}$ on a sample of each frozen powder. Dried mango powders were stored in plastic pots with a desiccation pastille at $-20^{\circ} \mathrm{C}$ until analysis.

Titratable acidity was measured using an automated titrimeter (TitroLine easy, Schott, Mainz, Germany) with a $0.05 \mathrm{~N} \mathrm{NaOH}$ solution. Total soluble solids were determined using a refractometer (Atago ATC-1E, Tokyo Japan).

\subsection{Oxidative stress and antioxidant response measurements}

Oxidant compounds $\left(\mathrm{H}_{2} \mathrm{O}_{2}, \mathrm{MDA}\right)$, antioxidant compounds (ascorbate, carotenoids), antioxidant enzymes (SOD, APX, CAT) and ascorbate-glutathione recycling enzymes (MDHAR, DHAR, GR) were determined as follows.

Hydrogen peroxide contents were assayed as described by Léchaudel et al. (2013) using frozen mango pulp (0.25 g) homogenized in an ice bath with $1 \mathrm{~mL} 0.1 \%(\mathrm{w}: \mathrm{v})$ TCA. A reaction mixture was prepared with the supernatant and $\mathrm{KI}$. Absorbance readings of triiodide ion $\left(\mathrm{I}_{3}{ }^{-}\right)$, resulting from the reaction between $\mathrm{H}_{2} \mathrm{O}_{2}$ and $\mathrm{KI}$, were taken at $390 \mathrm{~nm}$ by a microplate reader (BioTek Instruments, Inc., Winooski, VT, USA). $\mathrm{H}_{2} \mathrm{O}_{2}$ contents were quantified according to a standard curve.

The thiobarbituric acid (TBA) test, which determines malonyldialdehyde (MDA) as an end product of $\Omega-3$ polyunsaturated lipid peroxidation, was used to measure lipid peroxidation in fruits, as described by Léchaudel et al. (2013). The amount of MDA-TBA complex (red pigment) was calculated from the extinction coefficient: $155 \mathrm{mM}^{-1} \mathrm{~cm}^{-1}$.

AsA content was measured according to the microplate-adapted method developed by Léchaudel et al. (2013), omitting DHA content determination. A reaction mixture was prepared with the supernatant phosphate buffer $(0.2 \mathrm{mM})$, and a reagent, including TCA (10\%), orthophosphoric acid (42\% v:v), 2.2-bipyridyl ( $4 \%$ $\mathrm{w}: \mathrm{v})$ dissolved in ethanol (70\%) and ferric chloride (3\% w:v). The absorbance readings of the $\mathrm{Fe}(2)-2,2$-bipyridyl complex were taken at $525 \mathrm{~nm}$ with a microplate reader. The AsA contents were established according to a standard curve generated with commercial L-ascorbic.

All enzyme activities in their kinetic reactions were measured in $200 \mu \mathrm{L}$ volume at $25^{\circ} \mathrm{C}$, using a microplate reader. APX, DHAR and MDHAR activities were measured using the method of Murshed et al. (2008) SOD and CAT activities were measured using the method described in Léchaudel et al. (2013). Proteins were quantified using the Bradford assay (Bradford, 1976).

\subsection{Carotenoid analyses}

Carotenoid content was determined using a method based on Dhuique-Mayer et al. (2005). A total of $0.5 \mathrm{~g}$ of freshly lyophilized homogenized mango pulp was added to $15 \mathrm{~mL}$ of an ethanol:hexane (4:3, v:v) solution, and $50 \mu \mathrm{L}$ of $200 \mu \mathrm{g} \mathrm{mL}$ $\beta$-apo-8'-carotenal was injected into this solution using a glass micro syringe. The mixture was stirred for $15 \mathrm{~min}$ on a linear agitator and then centrifuged $\left(8000 \times g\right.$, at $4{ }^{\circ} \mathrm{C}$, for $\left.5 \mathrm{~min}\right)$. Supernatant was filtered and the centrifuge homogenized in $15 \mathrm{~mL}$ of an ethanol:hexane (4:3, v:v) solution for $15 \mathrm{~min}$. The solution was filtered and the two organic phases were pooled together. The extract was washed two times with $30 \mathrm{~mL}$ of $10 \% \mathrm{NaCl}(\mathrm{w}: \mathrm{v})$ and three times with $25 \mathrm{~mL}$ of ultrapure water. The remaining hexane phase was dried on anhydrous $\mathrm{Na}_{2} \mathrm{SO}_{4}$ and evaporated under low pressure. Concentrated carotenoid extract was adjusted to precisely $20 \mathrm{~mL}$. $5 \mathrm{~mL}$ of that solution were aliquoted, evaporated to dryness under $\mathrm{N}_{2}$ flux, solubilized in $50 \mu \mathrm{L}$ dichloromethane $(0.1 \%$ butylated hydroxy toluene, BHT) and $450 \mu \mathrm{L}$ of methanol:methyltert-butyl ether (MTBE) (1:1, v:v), filtered with a $0.45-\mu \mathrm{m}$ disk and injected into a high pressure liquid chromatography (HPLC) apparatus (Dionex Ultimate 3000, Dionex Co., Sunnyvale, CA, USA).

Carotenoids were quantified by HPLC coupled with a DAD detector. Identifications were performed by comparison between observed retention times and UV-vis spectra to commercial standards of all-trans-violaxanthine and $\beta$-carotene. The HPLC apparatus was a Dionex Ultimate 3000 (Dionex Co., Sunnyvale, CA, USA) that used a two-way mobile phase: (A): methanol:MTBE:water (96:2:2); and (B): MTBE:methanol:water (80:18:2). Solid phase was a reversed phase YMC C-30 $250 \times 4.6 \mathrm{~mm}, 5 \mu \mathrm{m}$, thermostated at $30^{\circ} \mathrm{C}$. Based on the above, identification compounds were classified as either xanthophylls or carotene compounds, and quantifications were established from standard curves and expressed as violaxanthine or $\beta$-carotene equivalents for xanthophylls and carotenes compounds, respectively.

ABA and ABA-GE analyses were carried out for green mature stages only (at harvest: $\mathrm{H} 1, \mathrm{H} 2$; after ripening: R1, R2). ABA extraction was performed by classical solid/liquid extraction using frozen pulps, methanol (80\%) and BHT as an antioxidant compound under agitation for $15 \mathrm{~h}$ at $4{ }^{\circ} \mathrm{C}$. This extract was filtered and the alcoholic phase was concentrated under vacuum at $37^{\circ} \mathrm{C}$. Ultrapure water was added to this concentrated extract and this mixture was successively acidified to $\mathrm{pH} 3$ and treated with polyvinyl polypyrolidone (PVPP) for $15 \mathrm{~min}$ at $4^{\circ} \mathrm{C}$. The mixture was filtered once again and its $\mathrm{pH}$ was adjusted to 2.5 and extracted three times with an equivalent volume of diethyl ether. The organic phase containing ABA was evaporated under vacuum, adjusted at $3 \mathrm{~mL}$ with diethyl ether and maintained at $-80^{\circ} \mathrm{C}$ until analysis. $\mathrm{NaOH}(5 \mathrm{~N})$ was added to the aqueous phase that contained ABA-GE in order to increase the $\mathrm{pH}$ value to 11 . The aqueous phase was heated to $60^{\circ} \mathrm{C}$ for $30 \mathrm{~min}$ for hydrolysis. Once the solution reached room temperature, it was acidified to $\mathrm{pH} 2.5$ and extracted twice with an equivalent volume of diethyl ether. The organic phase was evaporated under vacuum, adjusted to $3 \mathrm{~mL}$ with diethyl ether and maintained at $-80^{\circ} \mathrm{C}$ until analysis. Before HPLC-DAD-fluorometer analysis, extracts were evaporated under nitrogen flux and solubilized in $0.6 \mathrm{~mL}$ of methanol. Methanolic extracts were filtered with a $0.45 \mu \mathrm{m}$ PTFE syringe filter for injection. HPLC analysis was performed using a Dionex Ultimate 300 apparatus (Dionex Co., Sunnyvale, CA, USA) equipped with a diode array detector and a fluorimeter. The column used was a reversed phase, Interchim YP5B C18 $250 \times 4.6 \mathrm{~mm}, 5 \mu \mathrm{m}$.

\subsection{Statistical analysis}

Analyses of variance were performed to assess the effect of irrigation treatment on all the data presented in the tables and figures. Multiple comparisons between means of measurements at various maturity stages at harvest and after ripening were performed using the Tukey test to evaluate whether or not these means were 
significantly different. Linear and non-linear regressions between measurements were studied using $\operatorname{lm}($ ) and nls() functions. Irrigation treatment effects were evaluated using a Student $\mathrm{T}$ test on fruits from control and non-irrigated trees means. All statistical analyses were computed using R software (Team, 2012).

\section{Results}

\subsection{Fruit characteristics and ripening changes}

Fruits were grown during the 2010-2011 season that was characterized by a season with low rainfall, limited to the beginning and the end of the season, between August and September, and after mid-January (Fig. 1). Soil water storage for irrigated trees started with a maximum value of $130 \mathrm{~mm}$ and remained over $90 \%$ of this value during the whole season. On the other hand non-irrigated trees had a decreasing soil water storage, to almost $0 \mathrm{~mm}$ in the beginning of November. Fruits from the orchard without irrigation were harvested between 10 and 16 days earlier than those from the control one (Table 1 ), for the same physiological age, estimated from chlorophyll fluorescence. According to the irrigation treatment, the studied fruits, harvested at three maturity stages (H1-H3) showed significantly different maximum respiration values (RR) as well as different times from harvest to reach these maximum values of RR. The time to reach the highest RR decreased with maturity stage at harvest. The first two maturity stages corresponded to green mature stages, with a relatively lower RR value than the last one (H3), which were harvested at the beginning of the climacteric crisis. The respiration burst observed during fruit ripening was higher for fruits from non-irrigated trees than for control ones, with a difference of approximately $1.98,1.76$, and 1.65 times for $\mathrm{H} 1-\mathrm{H} 3$, respectively (Table 1 ).

Fruits from non-irrigated trees were significantly smaller than those from control trees, except for the last stage. Total soluble solids of fruit pulps increased during fruit maturation and their values were significantly higher in fruits from non-irrigated trees, except for the second harvest stage. Total titratable acidity followed the inverse path during ripening, and the differences between treatments were only observable at the first two stages at harvest (Table 2).

For the earliest harvest, control fruits had very low ABA contents. These contents increased in fruits from the second harvest stage and mainly during ripening to reach maximal levels in ripe fruits (Fig. 2A). Changes in ABA-GE contents were different, with lower levels and with a smaller increase in ripe fruits (Fig. 2B) Fruits from non-irrigated trees followed the same variations for their $A B A$ contents, whereas ABA-GE synthesis increased dramatically. Their contents were significantly higher by approximately 3 - to 5 -fold than those of control fruits. ABA-GE levels remained relatively stable during ripening for fruits from both irrigated and non-irrigated trees, except in ripe fruits from the first stage.

\subsection{Oxidative stress and antioxidant system defense}

After the first and second harvest stages, during the preclimacteric stage, control fruits had relatively low $\mathrm{H}_{2} \mathrm{O}_{2}$ contents (Fig. 1C). A significant change in $\mathrm{H}_{2} \mathrm{O}_{2}$ synthesis was observed at the third stage. The synthesis of $\mathrm{H}_{2} \mathrm{O}_{2}$ in fruits from non-irrigated trees increased as of the $\mathrm{H} 2$ stage, and the difference between treatments were significant in fruits as of the $\mathrm{H} 3$ stage. After ripening, $\mathrm{H}_{2} \mathrm{O}_{2}$ contents increased according to the maturity stage at harvest, and the highest values were reached in ripe fruits from the third harvest stage, regardless of the treatments. At this last stage, these contents were twice as high in fruits from non-irrigated trees as in the control fruits.
MDA contents increased with the maturity stage, regardless of the treatments, and the highest values were measured in ripe fruit (Fig 2D). MDA contents were higher in fruit from non-irrigated trees for the first harvest stage, but no significant difference was observed for the three maturity stages at harvest (Fig. 2D). After ripening, MDA contents were comparable for fruits from irrigated and nonirrigated trees, with the highest content in fruits from R3. Ascorbate contents were the highest at the first and second harvest stages, and decreased at the third, with values in control fruits equal to 51.33, 48.67, $32.73 \mathrm{mg} \mathrm{g} \mathrm{FW}^{-1}$ at H1-H3, respectively (Fig. 2E). Ascorbate contents observed in fruits from non-irrigated trees were higher than in the control ones, but these differences were significant only for $\mathrm{H} 1$ and $\mathrm{H} 2$ fruits. After ripening, the decrease in ascorbate content was particularly substantial for first and second harvest fruits, i.e., more than $50 \%$, and moderate for the $\mathrm{R} 3$ fruit, regardless of the treatments.

In contrast, carotenoid contents increased significantly with the maturity stage at harvest, from $\mathrm{H} 1$ to $\mathrm{H} 3$ (Fig. 2F). This carotenoid accumulation was enhanced during fruit ripening, and well-irrigated ripe mangoes cv. 'Cogshall' contained the highest contents in total carotenoids of approximately 23.60, 25.23 and $40.65 \mu \mathrm{g} \mathrm{FW}^{-1}$ for R1-R3 fruits, respectively. This increase in carotenoid content with maturity stage at harvest and after ripening was observed in the pulp of fruits from non-irrigated trees as well. However, the reduction in water supply tended to decrease the global carotenoid biosynthesis, even if the difference between treatments was not significant. In fruit from non-irrigated trees, carotenoid content reached a limitation, with a maximum content of approximately $30 \mu \mathrm{g} \mathrm{g} \mathrm{FW}^{-1}$, both at the second and third ripe stages.

The carotenoid pathway, represented by three key compound groups, $\beta$-carotene, xanthophylls and ABA (including ABA and ABA$\mathrm{GE}$ ), is illustrated in Fig. 3A and Fig. 3B. Carotene and xanthophyll compounds appear early in fruit maturation but remain at low levels (Fig. 3A). It can also be observed that carotenes and xanthophylls had comparable contents at these stages of maturity. Their contents increased slightly at the second harvest stage but the carotenoid burst clearly occurred during ripening (Fig. 3B). After ripening, xanthophyll contents were higher than those of carotenes. This evolution in the carotene/xanthophyll balance was observable through the $\beta$-carotene percentage of total carotenoid (Fig. 3C). As ripening progresses, the $\beta$-carotene proportion tends to decrease to the benefit of oxidized compounds. It also reaches a stable value of approximately $30 \%$ after ripening for both treatments, corresponding to a carotene/xanthophyll ratio of approximately 0.40 .

\subsection{Enzymatic antioxidant system defense}

Mango protein content increased along with maturity at harvest and most of the increase took place during ripening, raising the harvest value 4 - to 5 -fold. Differences in protein contents between irrigation treatments were not significant, except for fruit at harvest from the first and second stages (Table 3).

SOD activity measured at harvest showed an increase from the first to the last harvest stage. Its activity gradually increased in ripe control fruits, according to their maturity stage at harvest, with the highest activity for the last ripe stage (Table 3). SOD activity also increased in fruits from non-irrigated trees, from $\mathrm{H} 1$ to $\mathrm{H} 3$. An increase in SOD activity was observed after ripening without any effect of the maturity stage. SOD activity tended to be higher in fruits from non-irrigated trees at the first and second ripe stages compared to control fruits, but this difference was not significant. A significant difference between treatments was observed in fruits from $\mathrm{H} 3$, as was observed for $\mathrm{H}_{2} \mathrm{O}_{2}$ as well.

At harvest, the enzymes involved in $\mathrm{H}_{2} \mathrm{O}_{2}$ detoxification, i.e., CAT and APX, had almost no observable activity, especially for the first 


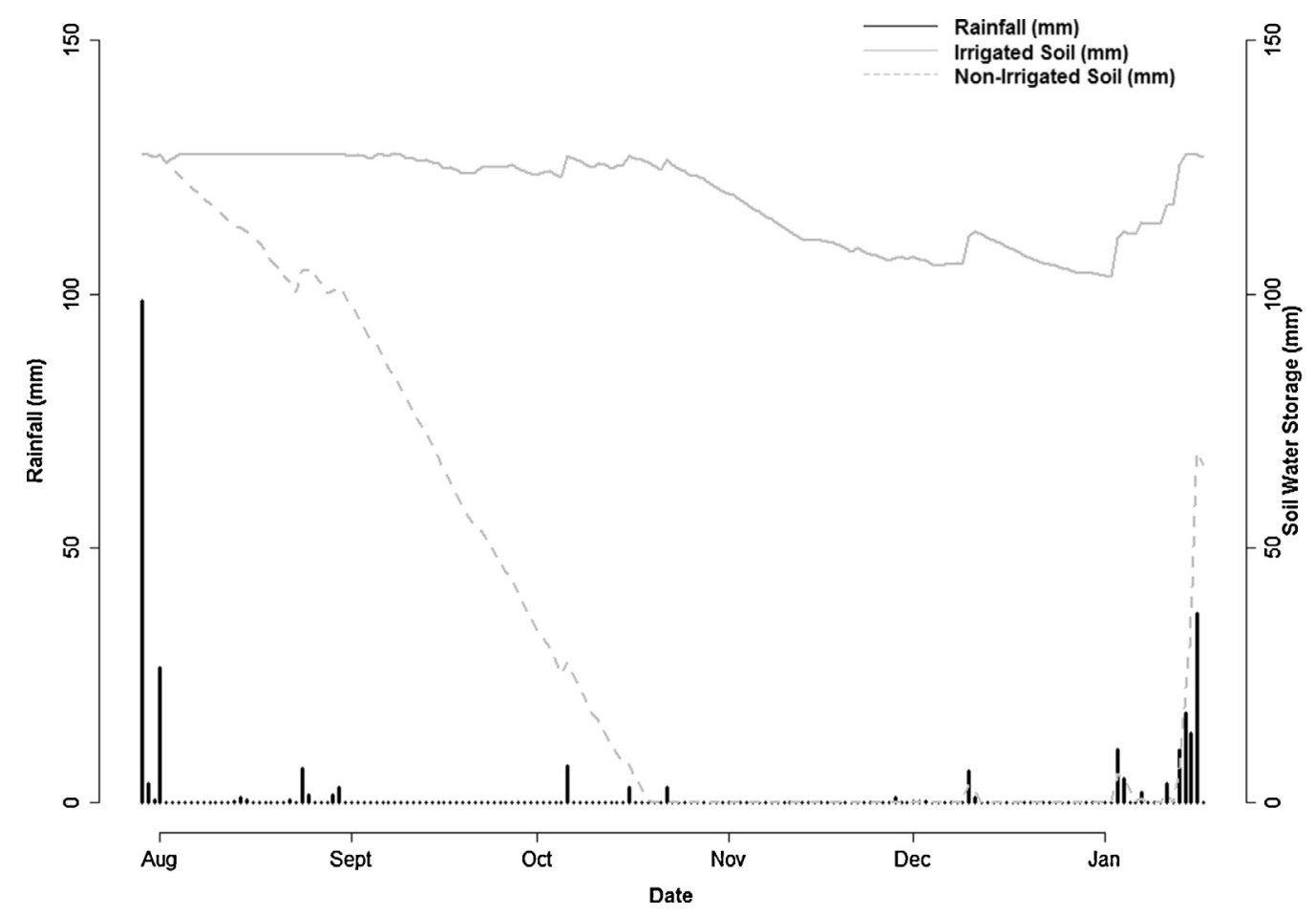

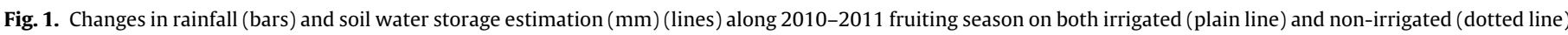
orchards. The depth of the root zone was $90 \mathrm{~cm}$.

Table 1

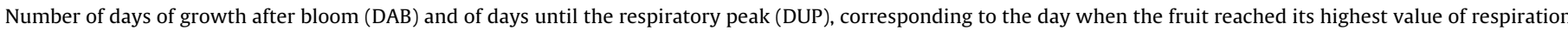

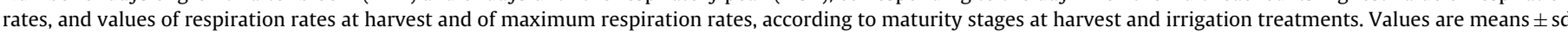
$(n=3)$.

\begin{tabular}{|c|c|c|c|c|}
\hline & Irrigation & $\mathrm{H} 1$ & $\mathrm{H} 2$ & H3 \\
\hline \multirow[t]{2}{*}{ DAB (days) } & Control & 108 & 123 & 130 \\
\hline & Non-irrigated & 94 & 107 & 120 \\
\hline \multirow[t]{3}{*}{ DUP (days) } & Control & $8.29 \pm 2.75$ & $9 \pm 0$ & $1.75 \pm 0.50$ \\
\hline & Non-irrigated & $11.20 \pm 0.45$ & $8.33 \pm 3.08$ & $2.2 \pm 0.84$ \\
\hline & Treatment effect & $*$ & n.s & n.s \\
\hline \multirow{3}{*}{$\begin{array}{l}\text { Respiration rates at } \\
\text { harvest }\end{array}$} & Control & $1.06 \pm 0.13$ & $1.66 \pm 0.32$ & $3.21 \pm 0.39$ \\
\hline & Non-irrigated & $1.35 \pm 0.12$ & $1.93 \pm 1.06$ & $4.86 \pm 0.12$ \\
\hline & Treatment effect & $*$ & n.s & $* *$ \\
\hline Maximum & Control & $4.07 \pm 0.32$ & $3.77 \pm 0.41$ & $3.40 \pm 0.23$ \\
\hline \multirow[t]{2}{*}{ respiration rates } & Non-irrigated & $6.05 \pm 0.43$ & $5.53 \pm 0.22$ & $4.97 \pm 0.19$ \\
\hline & Treatment effect & $* *$ & $* *$ & $* * *$ \\
\hline
\end{tabular}

n.s., *, **, *** mean that the effect of irrigation treatment is non-significant, significant at $P<0.05, P<0.01$, and $P<0.001$, respectively, for each maturity stage at harvest.

Table 2

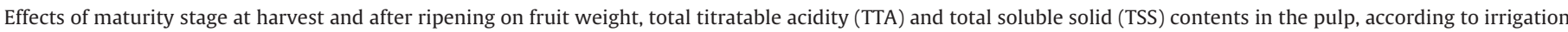
treatment. Values are means $\pm \mathrm{sd}(n=5)$.

\begin{tabular}{|c|c|c|c|c|c|c|c|}
\hline & Irrigation treatment & $\mathrm{H} 1$ & $\mathrm{H} 2$ & H3 & $\mathrm{R} 1$ & $\mathrm{R} 2$ & R3 \\
\hline $\begin{array}{l}\text { Weight } \\
\text { (g) }\end{array}$ & $\begin{array}{l}\text { Control } \\
\text { Non-irrigated } \\
\text { Treatment effect }\end{array}$ & $\begin{array}{l}300.27 \mathrm{a} \\
211.16 \mathrm{c} \\
*\end{array}$ & $\begin{array}{l}326.25 \mathrm{a} \\
235.06 \mathrm{~b}, \mathrm{c} \\
*\end{array}$ & $\begin{array}{l}312.13 \mathrm{a} \\
280.44 \mathrm{a}, \mathrm{b} \\
\text { n.s }\end{array}$ & $\begin{array}{l}- \\
- \\
-\end{array}$ & $\begin{array}{l}- \\
- \\
-\end{array}$ & $\begin{array}{l}- \\
- \\
-\end{array}$ \\
\hline $\begin{array}{l}\text { TTA } \\
\left(\text { meq } 100 g^{-1}\right)\end{array}$ & $\begin{array}{l}\text { Control } \\
\text { Non-irrigated } \\
\text { Treatment effect }\end{array}$ & $\begin{array}{l}34.04 \pm 1.93 \mathrm{c} \\
54.69 \pm 1.37 \mathrm{a} \\
* * *\end{array}$ & $\begin{array}{l}30.99 \pm 3.13 \mathrm{c} \\
47.56 \pm 5.59 \mathrm{~b} \\
* * *\end{array}$ & $\begin{array}{l}12.90 \pm 2.20 \mathrm{~d}, \mathrm{e} \\
16.30 \pm 3.97 \mathrm{~d} \\
\text { n.s }\end{array}$ & $\begin{array}{l}3.67 \pm 0.92 \mathrm{~g} \\
5.64 \pm 1.26 \mathrm{f}, \mathrm{g} \\
\text { n.s }\end{array}$ & $\begin{array}{l}3.46 \pm 1.35 \mathrm{~g} \\
4.16 \pm 2.11 \mathrm{f}, \mathrm{g} \\
\text { n.s }\end{array}$ & $\begin{array}{l}3.46 \pm 0.61 \mathrm{~g} \\
8.66 \pm 1.79 \mathrm{e}, \mathrm{f} \\
* *\end{array}$ \\
\hline TSS & $\begin{array}{l}\text { Control } \\
\text { Non-irrigated } \\
\text { Treatment effect }\end{array}$ & $\begin{array}{l}6.74 \pm 0.51 \mathrm{f} \\
10.14 \pm 1.13 \mathrm{~d}, \mathrm{f} \\
* *\end{array}$ & $\begin{array}{l}9.50 \pm 0.5 \mathrm{f} \\
10.58 \pm 2.08 \mathrm{~d}, \mathrm{f} \\
\text { n.s }\end{array}$ & $\begin{array}{l}14.90 \pm 4.91 \mathrm{c}, \mathrm{e} \\
18.88 \pm 2.42 \mathrm{a}, \mathrm{b} \\
*\end{array}$ & $\begin{array}{l}13.60 \pm 1.23 \text { d,e } \\
17.12 \pm 1.75 \text { a,b,c } \\
* *\end{array}$ & $\begin{array}{l}16.28 \pm 2.59 \text { b,e } \\
18.52 \pm 2.86 \text { a,b,c } \\
\text { n.s }\end{array}$ & $\begin{array}{l}18 \pm 0.61 \mathrm{a}, \mathrm{b}, \mathrm{c} \\
20.50 \pm 1.84 \mathrm{a} \\
*\end{array}$ \\
\hline
\end{tabular}

n.s., ${ }^{*}, * *, * * *$ mean that the effect of irrigation treatment is non-significant, significant at $P<0.05, P<0.01$, and $P<0.001$, respectively, for each maturity stage. Different letters indicate that data for each irrigation treatment are significantly different at $P<0.05$ (according to Tukey's multiple comparison test). 
Table 3

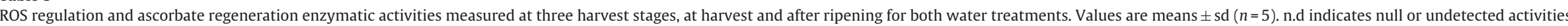

\begin{tabular}{|c|c|c|c|c|c|c|c|}
\hline & Irrigation & H1 & $\mathrm{H} 2$ & H3 & R1 & R2 & R3 \\
\hline $\begin{array}{l}\text { SOD } \\
\left(\mathrm{U} \mathrm{min}^{-1} \mathrm{gFW}^{-1}\right)\end{array}$ & $\begin{array}{l}\text { Control } \\
\text { Non-irrigated } \\
\text { Treatment effect }\end{array}$ & $\begin{array}{l}76.8 \pm 50.0 \mathrm{~d} \\
170.9 \pm 52.4 \mathrm{~b}, \mathrm{c}, \mathrm{d} \\
*\end{array}$ & $\begin{array}{l}264.3 \pm 33.0 \mathrm{a}, \mathrm{b}, \mathrm{c} \\
254.5 \pm 66.3 \mathrm{a}, \mathrm{b}, \mathrm{c} \\
\text { n.s }\end{array}$ & $\begin{array}{l}157.8 \pm 26.5 \mathrm{c}, \mathrm{d} \\
319.7 \pm 61.4 \mathrm{a} \\
* *\end{array}$ & $\begin{array}{l}237.5 \pm 39.8 \text { a,b,c } \\
271.8 \pm 84.4 \text { a,b,c } \\
\text { n.s }\end{array}$ & $\begin{array}{l}256.7 \pm 11.8 \mathrm{a}, \mathrm{b}, \mathrm{c} \\
322.5 \pm 70.0 \mathrm{a} \\
\text { n.s }\end{array}$ & $\begin{array}{l}310.9 \pm 89.6 \mathrm{a} \\
299.5 \pm 54.3 \mathrm{a}, \mathrm{b} \\
\text { n.s }\end{array}$ \\
\hline $\begin{array}{l}\text { CAT } \\
\left(\mathrm{mmol} \mathrm{min}^{-1}\right. \\
\left.\mathrm{gFW}^{-1}\right)\end{array}$ & $\begin{array}{l}\text { Control } \\
\text { Non-irrigated } \\
\text { Treatment effect }\end{array}$ & $\begin{array}{l}\text { n.d } \\
\text { n.d } \\
-\end{array}$ & $\begin{array}{l}\text { n.d } \\
\text { n.d } \\
-\end{array}$ & $\begin{array}{l}0.810^{-3} \pm 0.710^{-3} \mathrm{~b} \\
1510^{-3} \pm 810^{-3} \mathrm{~b} \\
\text { n.s }\end{array}$ & $\begin{array}{l}\text { n.d } \\
0.15 \pm 0.060 \text { a } \\
-\end{array}$ & $\begin{array}{l}0.12 \pm 0.09 \mathrm{a}, \mathrm{b} \\
0.16 \pm 0.03 \mathrm{a} \\
\text { n.s }\end{array}$ & $\begin{array}{l}0.11 \pm 0.09 \mathrm{a}, \mathrm{b} \\
0.18 \pm 0.07 \mathrm{a} \\
\text { n.s }\end{array}$ \\
\hline 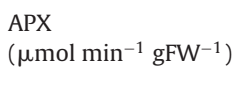 & $\begin{array}{l}\text { Control } \\
\text { Non-irrigated } \\
\text { Treatment effect }\end{array}$ & $\begin{array}{l}\text { n.d } \\
\text { n.d } \\
-\end{array}$ & $\begin{array}{l}\text { n.d } \\
\text { n.d } \\
-\end{array}$ & $\begin{array}{l}0.16 \pm 0.064 \mathrm{~d} \\
0.34 \pm 0.058 \mathrm{~d} \\
*\end{array}$ & $\begin{array}{l}2.77 \pm 1.17 \mathrm{c} \\
2.79 \pm 0.77 \mathrm{c} \\
\text { n.s }\end{array}$ & $\begin{array}{l}3.29 \pm 0.50 \mathrm{~b}, \mathrm{c} \\
4.52 \pm 0.85 \mathrm{a}, \mathrm{b} \\
\text { n.s }\end{array}$ & $\begin{array}{l}4.81 \pm 0.80 \mathrm{a} \\
5.19 \pm 0.47 \mathrm{a} \\
\text { n.s }\end{array}$ \\
\hline $\begin{array}{l}\text { MDHAR } \\
\left(\mu \mathrm{mol} \mathrm{min}^{-1} \mathrm{gFW}^{-1}\right)\end{array}$ & $\begin{array}{l}\text { Control } \\
\text { Non-irrigated } \\
\text { Treatment effect }\end{array}$ & $\begin{array}{l}\text { n.d } \\
\text { n.d } \\
-\end{array}$ & $\begin{array}{l}3.210^{-3} \pm 1.610^{-3} \mathrm{~d} \\
3.410^{-3} \pm 1.810^{-3} \mathrm{~d} \\
\text { n.s }\end{array}$ & $\begin{array}{l}0.21 \pm 0.03 \mathrm{~d} \\
0.36 \pm 0.16 \mathrm{c}, \mathrm{d} \\
\text { n.s }\end{array}$ & $\begin{array}{l}0.70 \pm 0.15 \mathrm{~b}, \mathrm{c}, \mathrm{d} \\
1.27 \pm 0.67 \mathrm{a}, \mathrm{b} \\
\text { n.s }\end{array}$ & $\begin{array}{l}1.02 \pm 0.47 \mathrm{a}, \mathrm{b}, \mathrm{c} \\
1.32 \pm 0.27 \mathrm{a}, \mathrm{b} \\
\text { n.s }\end{array}$ & $\begin{array}{l}1.45 \pm 0.19 \mathrm{a} \\
1.24 \pm 0.23 \mathrm{a}, \mathrm{b} \\
\text { n.s }\end{array}$ \\
\hline $\begin{array}{l}\text { DHAR } \\
\left(\mu \mathrm{mol} \mathrm{min}^{-1} \mathrm{gFW}^{-1}\right)\end{array}$ & $\begin{array}{l}\text { Control } \\
\text { Non-irrigated } \\
\text { Treatment effect }\end{array}$ & $\begin{array}{l}\text { n.d } \\
\text { n.d. } \\
-\end{array}$ & $\begin{array}{l}\text { n.d } \\
\text { n.d. } \\
-\end{array}$ & $\begin{array}{l}8.010^{-3} \pm 4.410^{-3} \mathrm{~d}, \mathrm{e} \\
\text { n.d } \\
-\end{array}$ & $\begin{array}{l}0.16 \pm 0.08 \mathrm{c,d} \\
0.06 \pm 0.06 \mathrm{c,d}, \mathrm{e} \\
\text { n.s }\end{array}$ & $\begin{array}{l}0.17 \pm 0.12 b, c \\
0.20 \pm 0.10 b, c \\
\text { n.s }\end{array}$ & $\begin{array}{l}0.36 \pm 0.04 \mathrm{a} \\
0.30 \pm 0.09 \mathrm{a}, \mathrm{b} \\
\text { n.s }\end{array}$ \\
\hline $\begin{array}{l}\text { GR } \\
\left(\mu \mathrm{mol} \mathrm{min}{ }^{-1} \mathrm{gFW}^{-1}\right)\end{array}$ & $\begin{array}{l}\text { Control } \\
\text { Non-irrigated } \\
\text { Treatment effect }\end{array}$ & $\begin{array}{l}\text { n.d } \\
6.910^{-3} \pm 4.110^{-3} \mathrm{c}, \mathrm{d} \\
-\end{array}$ & $\begin{array}{l}6.010^{-3} \pm 5.010^{-3} \mathrm{~d} \\
4.310^{-3} \pm 3.510^{-3} \mathrm{~d} \\
\text { n.s }\end{array}$ & $\begin{array}{l}0.08 \pm 0.03 \mathrm{c,d} \\
0.14 \pm 0.05 \mathrm{~b}, \mathrm{c}, \mathrm{d} \\
\text { n.s }\end{array}$ & $\begin{array}{l}0.31 \pm 0.11 \mathrm{a}, \mathrm{b}, \mathrm{c}, \mathrm{d} \\
0.41 \pm 0.11 \mathrm{a} \\
* *\end{array}$ & $\begin{array}{l}0.42 \pm 0.24 \mathrm{a}, \mathrm{b} \\
0.28 \pm 0.05 \mathrm{a} \\
\text { n.s }\end{array}$ & $\begin{array}{l}0.43 \pm 0.06 \mathrm{a}, \mathrm{b} \\
0.21 \pm 0.07 \mathrm{a}, \mathrm{b}, \mathrm{c} \\
\text { n.s }\end{array}$ \\
\hline $\begin{array}{l}\text { Protein } \\
\left(\mathrm{mggFW}^{-1}\right)\end{array}$ & $\begin{array}{l}\text { Control } \\
\text { Non-irrigated } \\
\text { Treatment effect }\end{array}$ & $\begin{array}{l}0.24 \pm 0.07 \mathrm{e} \\
0.44 \pm 0.07 \mathrm{de} \\
* *\end{array}$ & $\begin{array}{l}0.27 \pm 0.08 \text { de } \\
0.56 \pm 0.16 \text { cde } \\
*\end{array}$ & $\begin{array}{l}0.87 \pm 0.11 \mathrm{bcd} \\
1.10 \pm 0.14 \mathrm{abc} \\
\text { n.s }\end{array}$ & $\begin{array}{l}1.16 \pm 0.35 \mathrm{abc} \\
1.32 \pm 0.09 \mathrm{ab} \\
\text { n.s }\end{array}$ & $\begin{array}{l}1.21 \pm 0.48 \mathrm{ab} \\
1.41 \pm 0.33 \mathrm{ab} \\
\text { n.s }\end{array}$ & $\begin{array}{l}1.56 \pm 0.41 \mathrm{a} \\
1.66 \pm 0.28 \mathrm{a} \\
\text { n.s }\end{array}$ \\
\hline
\end{tabular}

n.s., ${ }^{*},{ }^{* *},{ }^{* * *}$ mean that the effect of irrigation treatment is non-significant, significant at $P<0.05, P<0.01$, and $P<0.001$, respectively, for each maturity stage

Different letters indicate that data for each irrigation treatment are significantly different at $P<0.05$ (according to Tukey's multiple comparison test). 

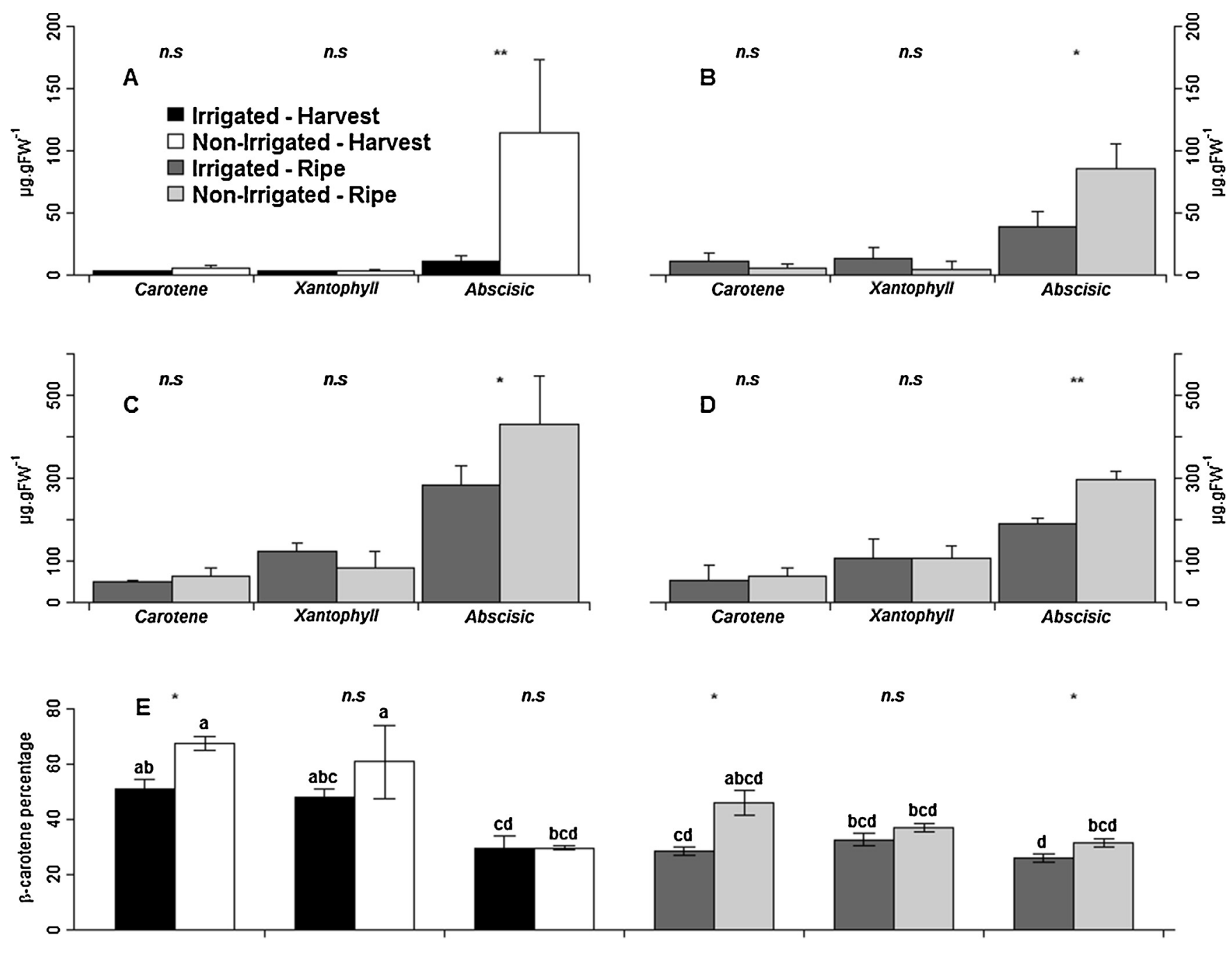

H-1

$\mathrm{H}-2$

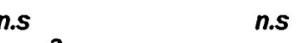

n.s

n.s

Abscisic

Fig. 2. Effects of maturity stage at harvest and after ripening on the contents of (A) abscisic acid ( $\left.\mu g \mathrm{gFW}^{-1}\right)$, (B) abscisic acid glucose ester $\left(\mu \mathrm{g} g \mathrm{FW}^{-1}\right)$, (C) hydrogen peroxide $\left(\mu \mathrm{mol} \mathrm{gFW}^{-1}\right),(\mathrm{D})$ malondialdehyde $(\mathrm{nmolgFW}-1),(\mathrm{E})$ ascorbate $\left(\mathrm{mg} 100 \mathrm{gFW}^{-1}\right),(\mathrm{F})$ total carotenoid content $\left(\mu \mathrm{gFW}^{-1}\right)$ in the pulp. Black bars correspond to control fruits analyzed at harvest, white bars correspond to fruits from non-irrigated orchard, analyzed at harvest dark gray bars correspond to fruits from control treatment analyzed after ripening and light gray bars correspond to fruits from non-irrigated trees analyzed after ripening. Values are means $\pm \operatorname{sd}(n=3)$.

n.s., ${ }^{*}, * *, * * *$ mean that the effect of irrigation treatment is non-significant, significant at $P<0.05, P<0.01$, and $P<0.001$, respectively, for each maturity stage.

Different letters indicate that data for each irrigation treatment are significantly different at $P<0.05$ (according to Tukey's multiple comparison test).

and second harvest stages, and a slight increase in activities was observed at the third stage (Table 3 ). CAT activity increased after ripening. No difference was observed between the ripe fruits from the first, second and third stages. Similar changes were observed in ripe fruits from non-irrigated trees, and although more activity was measured in ripe fruits than in control fruits, it was considered to be non-significant. In ripe fruits from early harvests, APX activity was similar for the first and second stages, but increased at the last stage. APX activity showed no significant difference between irrigation treatments. APX activity logically had an inverse exponential correlation with ascorbate content, regardless of the treatment $\left(R^{2}=0.722\right)$.

At harvest, MDHAR activity was not detected in control fruits for the first and second stages, whereas fruits from $\mathrm{H} 3$ showed a positive activity but one that remained low (Table 3 ). After ripening, MDHAR activity greatly increased, with a maximum value in fruits from the third stage. These results were directly linked to APX activity $\left(R^{2}=0.890\right)$ and inversely linked to the ascorbate content (exponential, $R^{2}=0.885$ ).
GR and DHAR had the same evolution with low activity at harvest and high activity after ripening, with a decrease in the highest activity intensity: $1.45,0.43$ and 0.36 , for MDHAR, GR and DHAR, respectively. This suggests that all the enzymes involved in the ascorbate regeneration pathway were involved during ripening, and that each enzyme has a different implication in the regeneration.

MDHAR activity showed no significant difference between irrigation treatments (Table 3). However, after ripening and depending on the irrigation treatment, this enzyme activity was higher in ripe control fruits from the first to the third stage, whereas the highest activity for fruits from non-irrigated trees was measured in ripe fruits from the first harvest and remained at the same high value in R2 and R3.

GR activity followed similar rate changes in fruits between irrigated and non-irrigated trees. It could be observed that first stage fruits from non-irrigated trees had the highest activity after ripening (Table 3), and that this high activity decreased at the second and third stages to reach half of this maximum value. 


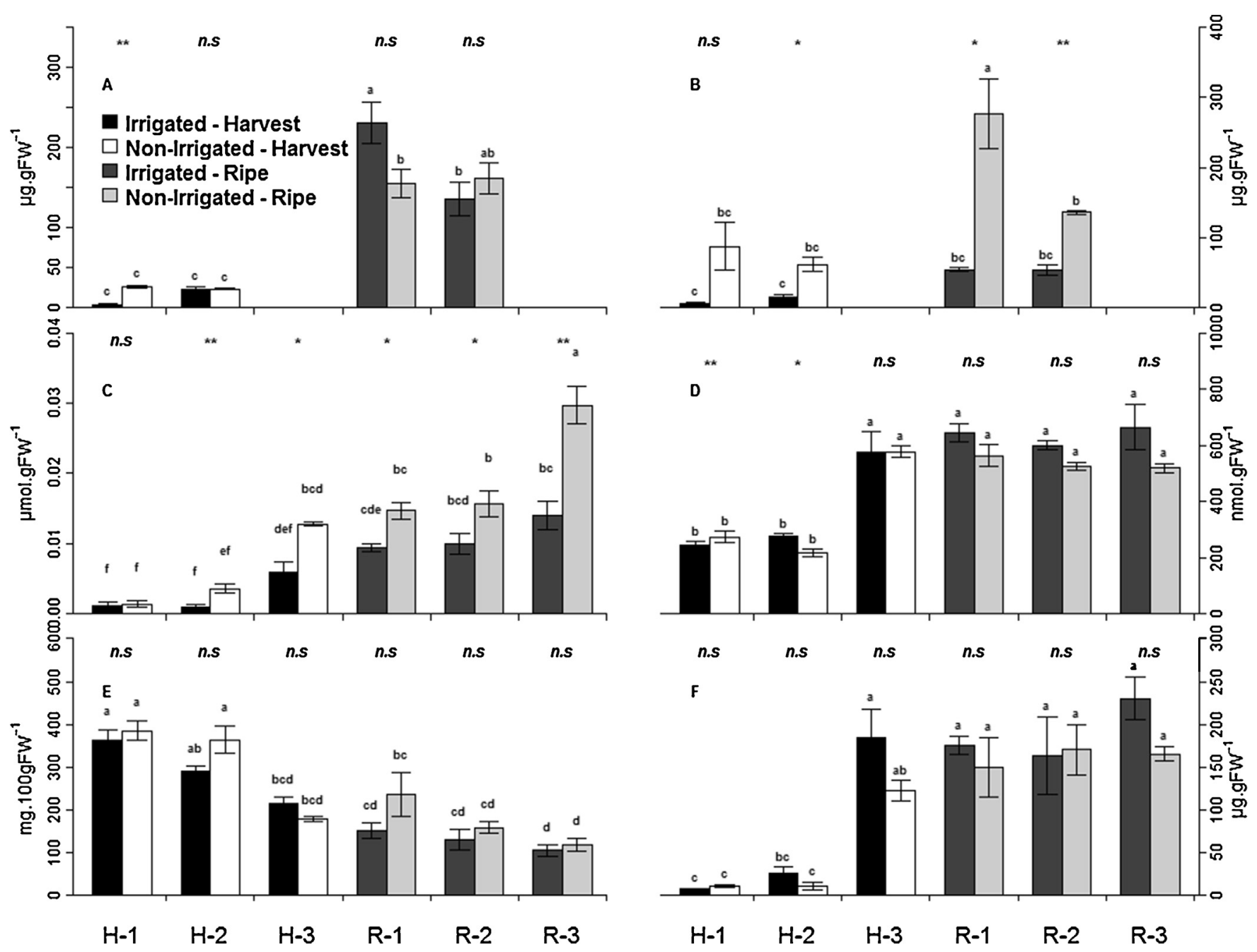

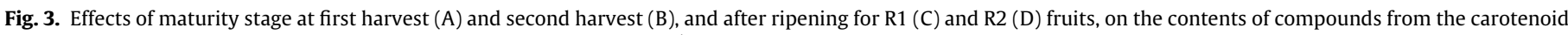

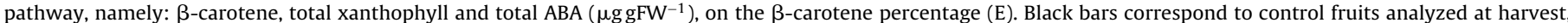

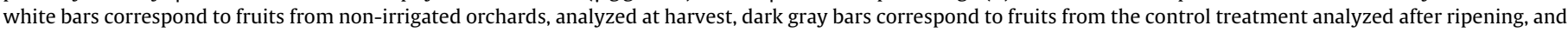
light gray bars correspond to fruits from non-irrigated trees analyzed after ripening.

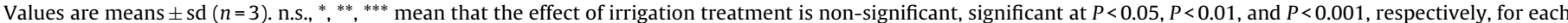
maturity stage. Different letters indicate that data for each irrigation treatment are significantly different at $P<0.05$ (according to Tukey's multiple comparison test).

DHAR activity was not detected in fruits from non-irrigated trees and was very low in control fruits at harvest. After ripening, DHAR activity increased along with maturity stage at harvest and reached a maximum activity at R3. However, it can be observed that DHAR activity at R1 was lower for fruits from non-irrigated trees than for control fruits.

\section{Discussion}

\subsection{Effect of maturity stage at harvest and water supply on fruit characteristics}

The effect of the suppression in irrigation water was the reduction of water and carbon supply for fruit growth, as indicated by the significant number of small fruits from non-irrigated trees at the first and second harvest stages. This negative effect of low water supply on fruit size was reported on other cultivars such as cv. “Osteen” (Durán Zuazo et al., 2011).

Total soluble solid values tended to increase during fruit development, from $\mathrm{H} 1$ to $\mathrm{H} 3$, and this difference was also observed in this study after postharvest ripening. Water deprivation increased the amount of TSS in fruits with significant differences for the first and second stages, at harvest and after ripening.

Total titratable acidity decreased along with the maturity stage at harvest and during ripening, as previously observed (Joas et al., 2011). The differences between fruits from irrigated and nonirrigated trees were significant at early maturity stages and fruits from non-irrigated trees remained more acidic than control fruits. This observation was also reported by Spreer et al. (2007) on cv. Chock Anan when reducing water availability for mango trees.

\subsection{Effect of maturity stage at harvest and fruit ripening on the oxidative stress and antioxidant response}

These results showed that mango ripening is characterized by an oxidative stress, as has been reported for other climacteric fruits such as tomato or guava (Pandey et al., 2013). Harvesting fruits at a green mature stage ( $\mathrm{H} 1$ and $\mathrm{H} 2$ ) apparently had no effect on their oxidative status, as shown by their similar contents in $\mathrm{H}_{2} \mathrm{O}_{2}$, but our results showed that it defined their potential oxidative status at the postharvest full ripe stage ( $\mathrm{R} 1$ and $\mathrm{R} 2$ ). Indeed, $\mathrm{H}_{2} \mathrm{O}_{2}$ content increased 5-folds and that of MDA almost doubled between the R1 and R2 stages, revealing an increase in both oxidant compounds 
and products of this oxidation. The observed increase in respiration rates linked to ripening is a cause of the accumulation of ROS production from mitochondrial cytochrome chain over-activity, as proposed by Tian et al. (2013). Respiration can also be achieved through the alternative oxidase (AOX) that does not produce ROS. In mango, however, this alternative respiration path is mainly active in the post-climacteric phase (Considine et al., 2001). We therefore demonstrated that the rate of accumulation of ROS mainly depends on fruit maturity at harvest. This was confirmed in ripe fruits from the mature stage, i.e., $\mathrm{H} 3$, which had higher $\mathrm{H}_{2} \mathrm{O}_{2}$ and MDA production compared to ripe fruits harvested earlier, i.e., the $\mathrm{H} 1$ and $\mathrm{H} 2$ stages. In fact, ripe fruit at R3 presented the highest values for these compounds. Moreover, these results also suggest that the time spent by the fruit on the tree influences the level of the oxidative stress in the fruit during its ripening.

SOD activity mainly followed the same changes during the ripening of mango as its $\mathrm{H}_{2} \mathrm{O}_{2}$ production, as seen by its activity at the third stage at harvest, which was twice that of the first and second stages, and then remained more or less constant in ripe fruits, in contrast with data observed on ripe papaya in which oxidative stress and its resulting damage continued to increase (Pandey et al., 2013).

Among the natural antioxidants, ascorbate is the most widespread and powerful compound. In mango, AsA contents were the highest in the flesh of fruits harvested at green mature stages and decreased during ripening. The decrease in AsA content with ripening was observed in pepper fruit, guava and acerola (Oliveira et al., 2012) and the authors suggested that the loss of AsA during ripening and senescence of the fruit may be due to the requirement of ascorbate for metabolic pathways involved during the climacteric rise. This evolution of AsA content was inversely correlated with changes in oxidative stress, suggesting a strong implication of ascorbate as an active antioxidant in this fruit (Sanmartin et al., 2000). It was observed that both oxidants and antioxidants remained at stable levels after ripening, regardless of the harvest stage. This stable state implies that a balance occurred from direct and enzymatic ROS scavenging, and that the AsA pool was maintained by de novo synthesis or regeneration, as has been suggested on tomato (Jiménez et al., 2002) and apple (Li et al., 2008).

In this study, the ascorbate regeneration cycle was evaluated through MDHAR, GR and DHAR activities. At the early stages (H1 and $\mathrm{H} 2$ ), the activity of ROS scavenging enzymes remained minimum and, in most cases, barely detectable. A significant increase in the activity of these enzymes was observed at the H3 maturity stage, concomitantly with the observed onset of the respiration rate increase and the changes in the oxidative status. This confirm that climacteric crisis of mango fruit is well correlated to ROS production, with the involvement of scavenging enzymes in the antioxidant defense system in mango (Zhao et al., 2009). At the full ripe stages, R1-R3, MDHAR had the strongest activity, followed by GR and DHAR, suggesting that the regeneration of AsA is determined by MDHAR rather than GR and DHAR, as observed in green and red peppers (Jiménez et al., 2002), in contrast to tomato where MDHAR drives the regeneration until the breaker stage and DHAR takes the lead until over the ripe stage (Jimenez et al., 2002). The other scavenging enzymes, APX and CAT, were also activated during ripening with higher activity for APX, according to data obtained on papaya (Pandey et al., 2013).

\subsection{Effect of a reduction in water supply on oxidative stress and the antioxidant response}

The oxidation level in the pulp was not influenced by the notirrigated conditions in fruits at harvest for the early harvest stages ( $\mathrm{H} 1$ and $\mathrm{H} 2$ ), but a significant difference was observed at the last harvest stage or after ripening, R1-R3, where irrigated fruits had
$50 \%$ less $\mathrm{H}_{2} \mathrm{O}_{2}$ than non-irrigated fruits These changes indicated that limited water supply induced oxidative stress, like in tomato (Murshed et al., 2013). The high contents in $\mathrm{H}_{2} \mathrm{O}_{2}$ in ripe fruits from non-irrigated trees can also be related in part to the significantly high respiration rates measured in these fruits since these ROS compounds are produced by an increase in mitochondrial activity (Tian et al., 2013). Other signals could also be implicated in ROS production such as ethylene, which is actively implicated in climacteric fruit ripening (Ebel et al., 1993). The increase in the content of reactive oxygen species in conditions of low water supply has been already shown by increasing the water stress intensity of tomato, another climacteric fruit (Murshed et al., 2013). However, MDA content did not present any difference between treatments, suggesting that if oxidation could induce membrane destruction, there is no direct correlation between MDA and $\mathrm{H}_{2} \mathrm{O}_{2}$ contents in mango pulp. MDA content increased during ripening to reach its maximal value in ripe fruits for those harvested at a green mature stage, in agreement with previous results concerning mango cv. Zill (Ding et al., 2007). For fruits in which ripening had already begun on the tree, like those in the H3 phase, the highest MDA content was measured at this stage, as observed on papaya (Resende and Martins, 2012).

A comparison of the evolution of oxidant content and oxidation markers suggested that $\mathrm{H}_{2} \mathrm{O}_{2}$ evolution did not take place in the same way in fruits from non-irrigated trees. This difference might be attributed to some variation in both molecular and enzymatic antioxidant activities. Ascorbate contents measured in pulp were approximately $20 \%$ higher in fruits from the earliest harvest stages ( $\mathrm{H} 1$ and $\mathrm{H} 2$ ). The increase in ascorbate content as a cell response to reduce oxidative stress was shown in tomato, where transcripts of ascorbate recycling (Murshed et al., 2013) and those of ascorbate synthesis (Alós et al., 2014) were up-regulated after water stress. This difference decreased with ripening, and ripe fruits in both treatments had the same content. In this experiment, no noticeable differences were observed between treatments for antioxidant and recycling enzymatic systems. The low water supply condition influenced fruit metabolism until their separation from the tree. Ascorbate content was clearly influenced by this fruit growth condition at green mature stages, as shown by the highest contents at the first and second stages. This positive effect induced by water limitation on ascorbate synthesis was reported for tomato (Dumas et al., 2003). Nevertheless, this influence could not be observed after ripening.

\subsection{Effect of maturity stage at harvest and a reduction in water supply on carotenoid and ABA biosynthesis}

The major carotenoid composition of mango cv. Cogshall is described here for the first time. This cultivar mainly contains two xanthophyll isomers esterified with low molecular weight fatty acids, namely all-trans-violaxanthine dibutyrate and 9-cisviolaxanthine dibutyrate, as well as ß-carotene, which together represent $70 \%$ of the carotenoids in ripe fruits. This type of carotenoid composition was observed in several commercial cultivars (Mercadante and Rodriguez-amaya, 1998).

Carotenoid content increased exponentially along with the climacteric crisis in accordance with data on mango cv. Tommy Atkins (Mercadante and Rodriguez-amaya, 1998) and some other non-climacteric fruits such as clementine (Poiroux-Gonord et al., 2012). We showed in this study that ripening influences the balance between carotenes and xanthophylls. Non-oxygenated carotenoids, mainly represented by $\beta$-carotene, were the major tetraterpenes present at the early stage in the fruit pulp of mango cv. Cogshall. As climacteric changes occurred, the carotenoid biosynthetic pathway was activated and accumulation began. This activation corresponded to an increase in xanthophyll syn- 
thesis that modifies the carotene/xanthophyll balance in favor of oxygenated molecules, i.e., violaxanthine isomers, creating a pseudo constant carotene-to-xanthophyll ratio after ripening of approximately 0.40 . This evolution toward an oxygenated form of carotenoid was also observed on "Red Paprika" (Capsicum annuum var. "Lycopersiciforme Rubrum") (Deli et al., 2001), where the carotenoid pathway tended to form the specific xanthophyll, capsanthin, to the detriment of lutein, and on orange fruits, where the carotenoid pathway tended to form violaxanthins and apocarotenals, to the detriment of lutein and $\beta$-carotene (Rodrigo et al., 2004).

A significant increase in ABA content was observed in the pulp of fruits between the two green mature stages at harvest. This was in accordance with results on 'Kensington' mangoes that indicated that ABA accumulated prior to the climacteric stage (Zaharah et al., 2013). Moreover, the highest ABA contents were analyzed after the respiration peak in ripe mangoes. These results confirmed the implication of this hormone in the ripening of climacteric fruit such as tomato (Zhang et al., 2009). Water deprivation primarily influenced the abscisic acid pathway, especially the accumulation of its conjugated form, in the pulp of Cogshall mango fruit. Changes in ABA content are often reported in the literature to play a role in the plant response to drought conditions (Hartung et al., 2002). The conjugated ABA/ABA-GE content is generally considered to be a water stress indicator (Hartung et al., 2002) because it is highly accumulated in leaf vacuoles from water stressed plants, and it can be reactivated as ABA (Dietz et al., 2000). In the pulp, the accumulation of $A B A$ can also have an impact on fruit ripening since $A B A$ plays an important role in the promotion of fruit ripening in combination with ethylene (Hartung et al., 2002; Zaharah et al., 2013). In our study, ABA contents in fruit pulp were not significantly different between treatments, as noted in the epidermis of drought stressed tomato (Davies and Bacon, 2000). ABA-GE has shown the highest significant values in the fruit flesh from the non-irrigated trees, according to the literature on leaves. Interestingly, ABA-GE contents in fruit from non-irrigated trees were similar, regardless of the maturity stage at harvest or after ripening, suggesting that there is no conversion in ABA-GE to ABA in the flesh. No significant difference in $A B A$ contents between fruits control and non-irrigated trees was observed. It could therefore be suggested that ABA-GE remained present in an inactive form, at least in fruit pulp, in order to avoid perturbations during fruit development and ripening. This accumulation of ABA-GE in the pulp can be related in part to novo ABA-GE synthesis from xanthophyll cleavage, as reported by Deluc et al. (2009) and to ABA-GE transported by xylem flow too, in response to the suppression of irrigation (Hartung et al., 2002).

Carotenoid contents were not affected by suppression of irrigation. The effects of reduced water supply on carotenoid accumulation have not been widely studied, with the exception of tomato fruit in which a consistent increase lycopene content but no effect on $\beta$-carotene or xanthophyll contents was reported (Stefanelli et al., 2010). It is important to highlight the fact that the biosynthesis of carotenoid remains exponential during ripening and that we had no evidence in this study to suggest an upregulation in synthesis linked to fruit growth conditions, such as carbon limitation (Poiroux-Gonord et al., 2013). However, such conditions unbalanced the relative carotene content. The difference between irrigation conditions concerns mainly the time it takes to reach the pseudo constant carotene-to-xanthophyll ratio. In fact, since both treatments have a similar evolution after harvest, fruits from non-irrigated trees only reach this pseudo equilibrium at the second stage. This delay could be explained by a disturbance in the biosynthesis pathway due to ROS compounds, in response to the decrease in water supply during fruit development. It was demonstrated on bell pepper that ROS act as a novel class of second messengers that mediate intense carotenoid synthesis (Bouvier,
1998). The activity of enzymes involved in the carotenoid biosynthesis pathway and carotenoid composition depended on the level of ROS. In mango pulp, a decrease in water supply caused an oxidative stress that can be observed on the tree when fruit ripening has begun. Before climacteric changes occur, high ascorbate contents lead to non-significant differences in $\mathrm{H}_{2} \mathrm{O}_{2}$ contents between treatments. It might also be interesting to focus in the involvement of ROS as regulators in the carotenoid synthesis pathway to better understand their accumulation in fruits submitted to water supply.

In conclusion, the results of this study highlight that the ripening of climacteric fruits, as observed in mango, is accompanied by an oxidative stress, where high respiration rates were concomitantly measured with high $\mathrm{H}_{2} \mathrm{O}_{2}$ and MDA contents. The defense response of fruits takes the form of a complex enzymatic system using ascorbate as substrate and regenerating it. We observed a decrease and stabilization of ascorbate content sustaining the idea that fruits maintain a constant equilibrium during ripening to overcome early aging and cell death. However, since fruits from early harvests had a lower antioxidant defense in response to ripening, this latter might depend on the maturity stage at harvest. Further investigations might help to understand the link between maturity and antioxidant response from fruits. We also observed that carotenoid accumulation increased exponentially during ripening, giving an increasing proportion to oxygenated compounds.

Suppression of water irrigation increased respiration rates during ripening and therefore $\mathrm{H}_{2} \mathrm{O}_{2}$ contents. However antioxidant enzymes response did not show significant differences between irrigation treatments. We hypothesize that the high intensity level of oxidative stress involved in ripening could mask the part linked to the reduction in water supply. Carotenoid contents also were not significantly affected by the irrigation treatments. ABA-GE as an indicator of water stress clearly showed that fruits from nonirrigated trees were significantly impacted by the treatment. Basing on the analysis of carotenoids it appears that at harvest most of the ABA-GE accumulated in fruits was coming from xylem flow while after separation from the tree ABA was de novo synthesized from fruits xanthophyll.

\section{Acknowledgments}

The authors gratefully acknowledge C. Soria (CIRAD, UR HortSys, Reunion Island) for technical assistance during the field experiments, and J. Minier (CIRAD, UMR Qualisud, Reunion Island) and M. Darnaudery (CIRAD, UR HortSys, Reunion Island) for assistance with the biochemical analyses. We would thank the Conseil Régional de La Réunion for PhD funding of Rémy Rosalie We would also like to thank G. Wagman for revising the manuscript and improving the English.

\section{References}

Allen, R.G., Pereira, L.S., Raes, D., 1998. Crop evapotranspiration-Guidelines for computing crop water requirements. FAO, 300.

Alós E., Rodrigo M.J., Zacarías L., Differential transcriptional regulation of l-ascorbic acid content in peel and pulp of citrus fruits during development and maturation, 239, 2014, 1113-1128.

Azevedo de, P., Silva da, B., Silva da, V., 2003. Water requirements of irrigated mango orchards in northeast Brazil. Agric. Water Manage. 58, 241-254.

Blokhina, O., 2003. Antioxidants, oxidative damage and oxygen deprivation stress: a review. Ann. Bot. 91, 179-194.

Bouvier, F., 1998. Induction and control of chromoplast-specific carotenoid genes by oxidative stress. J. Biol. Chem. 273, 30651-30659.

Bradford, M., 1976. A rapid and sensitive method for the quantitation of microgram quantities of protein utilizing the principle of protein-dye binding. Anal. Biochem. 72, 248-254

Chopart, J.L., Le Mézo, L., Mézino, M., 2009. PROBE-w (PROgramme de Bilan de l'Eau): Logiciel De Modélisation Du Bilan Hydrique Dans Un Sol Cultivé. CIRAD, Montpellier, France, p. 18.

Chopart, J.L., Vauclin, M., 1990. Water balance estimation model: field test and sensitivity analysis. Soil Sci. Soc. Am. J. 54, 1377-1384. 
Considine, M., Daley, D., Whelan, J., 2001. The expression of alternative oxidase and uncoupling protein during fruit ripening in mango. Plant Physiol. 126, 1619-1629.

Dat, J., Vandenabeele, S., Vranová, E., Van Montagu, M., Inzé, D., Van Breusegem, F. 2000. Dual action of the active oxygen species during plant stress responses. Cell Mol. Life Sci. 57 (May), 779-795.

Davies, W., Bacon, M., 2000. Regulation of leaf and fruit growth in plants growing in drying soil: exploitation of the plants' chemical signalling system and hydraulic architecture to increase the efficiency of water use in agriculture. J. Exp. Bot. 51, 1617-1626.

Deli, J., Molnár, P., Matus, Z., Tóth, G., 2001. Carotenoid composition in the fruits of red paprika (Capsicum annuum var. lycopersiciforme rubrum) during ripening; biosynthesis of carotenoids in red paprika. J. Agric. Food Chem. 49, 1517-1523.

Deluc, L.G., Quilici, D.R., Decendit, A., Grimplet, J., Wheatley, M.D., Schlauch Ka, et al., 2009. Water deficit alters differentially metabolic pathways affecting important flavor and quality traits in grape berries of Cabernet Sauvignon and Chardonnay. BMC Genomics 10, 212-245.

Dhuique-Mayer, C., Caris-Veyrat, C., Ollitrault, P., Curk, F., Amiot, M.-J., 2005. Varietal and interspecific influence on micronutrient contents in citrus from the Mediterranean area. J. Agric. Food Chem. 53, 2140-2145.

Dietz, K.J., Sauter a, Wichert, K., Messdaghi, D., Hartung, W., 2000. Extraular beta-glucosidase activity in barley involved in the hydrolysis of ABA glucose conjugate in leaves. J. Exp. Bot. 51 (May), 937-944.

Ding, Z.-S., Tian, S.-P., Zheng, X.-L., Zhou, Z.-W., Xu, Y., 2007. Responses of reactive oxygen metabolism and quality in mango fruit to exogenous oxalic acid or salicylic acid under chilling temperature stress. Physiol. Plant 130, 112-121.

Dumas, Y., Dadomo, M., Di Lucca, G., Grolier, P., 2003. Effects of environmental factors and agricultural techniques on antioxidantcontent of tomatoes. J. Sci. Food Agric. 83, 369-382.

Durán Zuazo, V.H., Pleguezuelo, C.R.R., Tarifa, D.F., 2011. Impact of sustained-deficit irrigation on tree growth, mineral nutrition, fruit yield and quality of mango in Spain. Fruits 66, 257-268.

Ebel, R., Proebsting, E., Patterson, M., 1993. Regulated deficit irrigation may alter apple maturity, quality, and storage life. HortScience 28, 141-143.

Gill, S.S., Tuteja, N., 2010. Reactive oxygen species and antioxidant machinery in abiotic stress tolerance in crop plants. Plant Physiol. Biochem. 48, 909-930.

Hartung, W., Sauter, A., Hose, E., 2002. Abscisic acid in the xylem: where does it come from, where does it go to? J. Exp. Bot. 53 (January), 27-32.

Jimenez, A., Creissen, G., Kular, B., Firmin, J., Robinson, S., Verhoeyen, M., et al., 2002. Changes in oxidative processes and components of the antioxidant system during tomato fruit ripening. Planta 214 (March), 751-758.

Jiménez, A., Gómez, J., Navarro, E., Sevilla, F., 2002. Changes in the antioxidative systems in mitochondria during ripening of pepper fruits. Plant Physiol. Biochem. 40, 515-520.

Joas, J., Caro, Y., Lechaudel, M., 2009. Comparison of postharvest changes in mango (cv. Cogshall) using a ripening class index (Rci) for different carbon supplies and harvest dates. Postharvest Biol. Technol. 54, 25-31.

Joas, J., Caro, Y., Léchaudel, M., 2004. Ripening behaviour of mango (cv. Lirfa) in relation to carbon nutrition stress and harvest period. Int. Conf. Postharvest Unltd Downunder 687, 401-404.

Joas, J., Vulcain, E., Desvignes, C., 2011. Physiological age at harvest regulates the variability in postharvest ripening, sensory and nutritional characteristics of mango (Mangifera indica L.) cv. Coghshall due to growing conditions. J. Sci. Food Agric. 92, 1282-1290.

Léchaudel, M., Lopez-Lauri, F., Vidal, V., Sallanon, H., Joas, J., 2013. Response of the physiological parameters of mango fruit (transpiration, water relations and antioxidant system) to its light and temperature environment. J. Plant Physiol. $170,567-576$.

Lechaudel, M., Urban, L., Joas, J., 2010. Chlorophyll fluorescence, a nondestructive method to assess maturity of mango fruits (cv. 'Cogshall') without growth conditions bias. J. Agric. Food Sci. 58, 7532-7538.
Li, M.-J., Ma, F.-W., Zhang, M., Pu, F., 2008. Distribution and metabolism of ascorbic acid in apple fruits (Malus domestica Borkh cv. Gala). Plant Sci. 174, 606-612.

Mercadante, A.Z., Rodriguez-amaya, D.B., 1998. Effects of ripening, cultivar differences, and processing on the carotenoid composition of mango. J. Food Chem. 8561, 128-130.

Mittler, R., Vanderauwera, S., 2004. Reactive oxygen gene network of plants. Trends Plant Sci. 9, 490-498.

Murshed, R., Lopez-Lauri, F., Sallanon, H., 2013. Effect of water stress on antioxidant systems and oxidative parameters in fruits of tomato (Solanum lycopersicon L. cv. Micro-tom). Physiol. Mol. Biol. Plants 19, 363-378.

Oliveira, L.D.S., Farley, C., Moura, H., Brito De, E.S., Virg, R., Mamede, S., et al., 2012. Antioxidant metabolism during fruit development of different acerola (Malpighia emarginata D.C.) clones. J. Agric. Food Chem. 60, 7957-7964.

Pandey, V.P., Singh, S., Jaiswal, N., Awasthi, M., Pandey, B., Dwivedi, U.N., 2013. Papaya fruit ripening: ROS metabolism, gene cloning, characterization and molecular docking of peroxidase. J. Mol. Catal. B Enzym. 98, 98-105.

Poiroux-Gonord, F., Fanciullino, A.-L., Bert, L., Urban, L., 2012. Effect of fruit load on maturity and carotenoid content of clementine (Citrus clementina Hort. ex Tan.) fruits. J. Sci. Food Agric. 92, 2076-2083.

Poiroux-Gonord, F., Fanciullino, A.-L., Poggi, I., Urban, L., 2013. Carbohydrate control over carotenoid build-up is conditional on fruit ontogeny in clementine fruits. Physiol. Plant 147, 417-431.

Raunet, M., Langellier, P., 2011. Hydrodynamical Characteristics of Soils. CIRAD, Montpellier.

Resende, E., Martins, P., 2012. Oxidative processes during ‘Golden’ papaya fruit ripening. Braz. J. Plant Physiol. 24, 85-94.

Rodrigo, M.-J., Marcos, J.F., Zacarías, L., 2004. Biochemical and molecular analysis of carotenoid biosynthesis in flavedo of orange (Citrus sinensis L.) during fruit development and maturation. J. Agric. Food Chem. 52, 6724-6731.

Sanmartin, M., Davey, M.W., Montagu Van, M., Inze, D., Kanellis, A., Smirnoff, N., et al., 2000. Review plant L-ascorbic acid: chemistry, function, metabolism, bioavailability and effects of processing. J. Sci. Food Agric. 860, $825-860$.

Singh, S.P., Singh, Z., Swinny, E.E., 2012. Climacteric level during fruit ripening influences lipid peroxidation and enzymatic and non-enzymatic antioxidative systems in Japanese plums (Prunus salicina Lindell). Postharvest Biol. Technol. $65,22-32$.

Spreer, W., Nagle, M., Neidhart, S., 2007. Effect of regulated deficit irrigation and partial rootzone drying on the quality of mango fruits (Mangifera indica L., cv. 'Chok Anan'). Agric. Water Manage. 88, 173-180.

Spreer, W., Ongprasert, S., Hegele, M., 2009. Yield and fruit development in mango (Mangifera indica L. cv. Chok Anan) under different irrigation regimes. Agric. Water Manage. 96, 574-584.

Stefanelli, D., Goodwin, I., Jones, R., 2010. Minimal nitrogen and water use in horticulture: effects on quality and content of selected nutrients. Food Res. Int 43, 1833-1843.

Taylor, P., Masibo, M., 2012. Mango bioactive compounds and related nutraceutical properties-a review. Food Rev. Int. 25, 346-370.

Team, 2012. R: A Language and Environment for Statistical Computing.

Tian, S., Qin, G., Li, B., 2013. Reactive oxygen species involved in regulating fruit senescence and fungal pathogenicity. Plant Mol. Biol. 82, 593-602.

Zaharah, S.S., Singh, Z., Symons, G.M., Reid, J.B., 2013. Mode of action of abscisic acid in triggering ethylene biosynthesis and softening during ripening in mango fruit. Postharvest Biol. Technol. 75, 37-44.

Zhang, M., Yuan, B., Leng, P., 2009. The role of ABA in triggering ethylene biosynthesis and ripening of tomato fruit. J. Exp. Bot. 60, 1579-1588.

Zhao, Z., Cao, J., Jiang, W., 2009. Maturity-related chilling tolerance in mango fruit and the antioxidant capacity involved. J. Sci. Food Agric. 89, 304-309. 